\title{
Can R\&D subsidies counteract the economic crisis? - Macroeconomic effects in Germany
}

\author{
Hans-Ulrich Brautzsch ${ }^{1}$, Jutta Günther ${ }^{2}{ }^{*}$, Brigitte Loose ${ }^{1}$, Udo Ludwig ${ }^{1,3}$, Nicole Nulsch ${ }^{1}$ \\ ${ }^{1}$ Halle Institute for Economic Research (IWH), Germany \\ ${ }^{2}$ University of Bremen, Germany \\ ${ }^{3}$ University of Leipzig, Germany
}

Corresponding author: Jutta Günther, University of Bremen, Email: jutta.guenther@unibremen.de; phone: +4942121866632

*IWH until March 2014

\begin{abstract}
During the economic crisis of 2008 and 2009, governments in Europe stabilized their economies by means of fiscal policy. After decades of absence, deficit spending was used to counteract the heavy decline in demand. In Germany, public spending went partially into R\&D subsidies in favor of small and medium sized enterprises. Applying the standard open inputoutput model, the paper analyzes the macroeconomic effects of R\&D subsidies on employment and production in the business cycle. Findings in the form of backward multipliers suggest that R\&D subsidies have stimulated a substantial leverage effect. Almost two thirds of the costs of $R \& D$ projects are covered by the enterprises themselves. Overall, a subsidized R\&D program results in a production, value added and employment effect that amounts to at least twice the initial financing. Overall, the R\&D program counteracts the decline of GDP by $0.5 \%$ in the year 2009. In the year 2010 the effects are already procyclical since the German economy recovered quickly. Compared to the strongly discussed alternative uses of subsidies for private consumption, R\&D spending is more effective.
\end{abstract}

Keywords: economic crisis, R\&D subsidies, stabilization policy, macroeconomic effects, backward multipliers, input-output model

Publication information: This article was published as Brautzsch, H. U., Günther, J., Loose, B., Ludwig, U., \& Nulsch, N. (2015). Can R\&D subsidies counteract the economic crisis? Macroeconomic effects in Germany. Research Policy, 44(3), 623-633, DOI:

$\underline{10.1016 / \text { j.respol.2014.11.012 }}$ 


\section{Introduction}

At the end of 2008, a severe economic crisis dealt a heavy blow to the global economy as a whole. The decline of effective demand caused by a loss of confidence and long-term expectations led to a worldwide economic slowdown which had negative effects on production, employment, investment and consumption. Consequently, in 2009 the gross domestic product of the four largest economies in the Euro Zone declined by between 3 and 6 percent (see figure 1). Most national governments used fiscal policy measures to support and stabilize the demand side of the economy. In Germany, this fiscal policy included public spending in various areas, among them the Research and Development (R\&D) activities of private enterprises.

\section{Figure 1}

Growth rates of GDP in the four largest economies of the Euro Zone since 2000

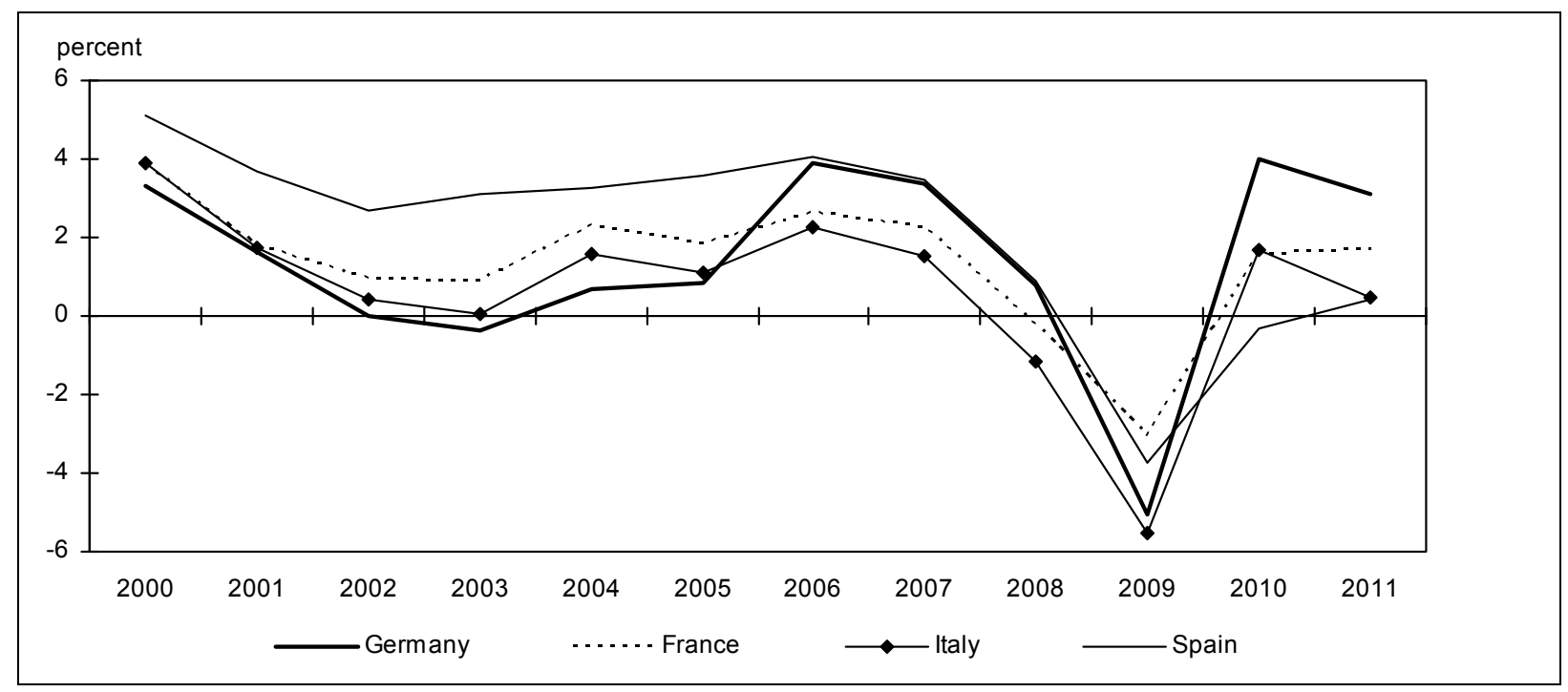

Source: Eurostat

The role of $R \& D$ in economic growth has been a subject of economic literature for many years. It is generally acknowledged that investments in R\&D contribute to growth and competitiveness through product and process innovations. Endogenous growth theory shows that spillover effects from R\&D investments are essential for long-term economic growth (Grossman and Helpman 1992, Romer 1986 and 1990). In practice, SMEs typically face problems in recruiting sources to finance their own R\&D (Czarnitzki and Hottenrott 2011; Rammer 2009). During the 
crisis of 2008 to 2009 this challenge became even greater and small companies in particular faced difficulties in keeping their level of R\&D investment (European Commission 2011, Archibugi and Filippetti 2011, Paunov 2012). Hence, in order to counteract the negative implications of the economic crisis and to encourage long-term economic development, the German government decided in February 2009 to increase the budget for one of the largest German R\&D programs, the "Central Innovation Program for SMEs" (ZIM), by 900 million Euros for the years 2009 and 2010. At the same time, the German government decided to enlarge the group of firms eligible for this program going beyond the official definition of SMEs (up to 250 employees). A temporary opening for firms with up to 1000 employees took place due to the serious and extraordinary situation. This was a political decision like all actions undertaken as fiscal policy measures during that time (OECD 2009). The focus of the R\&D program, however, was kept on SMEs. Stabilization of production and employment are fundamental arguments in favor of budget increases and widening of the scope of firms eligible for R\&D subsidies in Germany. Therefore, this paper deals with an empirical investigation of whether and to what degree this increased R\&D program counteracted the decline in effective demand during the economic crisis (business cycle). The long term growth effects which become effective much later due to innovations in the form of new products or production processes also exist, but they are not related to stabilization policy in the present and thus not subject to this paper.

At the macroeconomic level, empirical analyses of the impact of $R \& D$ spending focus on productivity spillovers (e.g. Guellec and van Pottelsberghe de la Potterie 2001; Levy and Terleckyj 1983; OECD 2008). Some attempts have also been made to quantify the impact of non-material capital on the development of economic productivity (van Ark et al. 2009). 
Existing macroeconomic studies typically focus on $R \& D$ as a means that in the medium to longterm contributes to an expansion of the production potential and thus to economic growth. In contrast to this view and with respect to our subject $-R \& D$ as a short-term remedy in an economic crisis - we are interested in the economic effects which occur immediately when running $R \& D$ projects.

In order to investigate the short-term stabilization effects of $R \& D$ empirically, we need to capture the demand brought about by additional $R \& D$ projects, in other words the pressure on production (and employment) in supplier industries as well as the effects of the income generated, which in turn stimulates production in consumer goods industries and so forth. In order to study the short-term effects of the German R\&D program, we have applied the inputoutput method.

A major innovation of this paper is the fact that we treat $R \& D$ in the input-output model as a process of capital formation (investment) and not as a consumption process, as is usually the case in national accounting. The re-definition of $R \& D$ as an investment is made because it comes much closer to capturing the nature of $R \& D$. In practice, $R \& D$ contributes to the stock of knowledge and does not disappear in one production cycle like an intermediate product; rather, the results of $\mathrm{R} \& \mathrm{D}$ endure for a longer period. Current discussions are aimed at changing national accounts on exactly this point (European Commission et al. 2009), but this has not yet been realized. We anticipate this insight in this paper and provide a macro analysis where R\&D is treated as a capital good.

The next two sections describe the methodology and the data set used. Section four applies the method and analyzes the leverage effect as well as the effects on production and employment. A discussion of the results and concluding remarks follow in the last section. 


\section{Conceptual framework}

\subsection{Literature review and subject of analysis}

R\&D subsidies are subject to many theoretical and empirical studies. One important strand of literature deals with the selection problem of R\&D and innovation programs (e.g. Buscom 2000, Segerstrom 2000, Takalo and Tanayama 2010), another with the signaling effects of R\&D subsidies (e.g. Lerner 1999; Kleer 2009, Meuleman and de Maeseneire, 2012). Furthermore, in recent times there is a growing literature dealing with the effects of $R \& D$ subsidies on the economic performance of firms using microeconometric methods and micro data (e.g. Alecke at al. 2012, Czarnitzki et al. 2011, González and Pazó 2008, Schwartz et al. 2012). David et al. (2000) in a larger meta study of this type of empirical analyses find mixed results, particularly with respect to crowding out effects. The objective of these microeconometric studies is not to quantify the macroeconomic effects of R\&D subsidies but to focus on firm level behavior and individual performance effects. Finally, there are analyses with a macroeconomic perspective and methodology, too. The main focus is long term growth and productivity effects of R\&D as a consequence of knowledge production and enlargement of the production potential (supply side) of an economy (for an overview see e.g. OECD 2008), productivity effects that improve national competitiveness, and the capability of exports in the long run. The objective of our paper goes beyond these empirical studies. We are interested in the short term stabilization effects of R\&D resulting solely out of the increase of demand for domestically produced products when running $R \& D$ projects. That means, we switch on the demand side of the economy. A typical method to quantify the macroeconomic demand side effects is the inputoutput analysis (Miller and Blair 2009). The methodology will be explained in more detail below. 
Several studies also use the input-output method to analyze inter-industry flows of embodied R\&D. Here it is assumed that an initial innovation is incorporated in the industry`s product, which may involve a new or improved commodity or simply the improvement of the production process. The product is regarded as a carrier of technological progress. Since other industries use this product as an intermediate input, the innovation becomes embodied in all products, including those used for final demand (consumption, capital formation and exports). This type of inter-industry diffusion is traditionally analyzed by backward and forward multipliers in an input-output context (Haukness and Knell 2009). In this context, two questions can be answered: (1) How much R\&D is embodied in the final output of industry $\mathbf{j}$ or (2) what portion of R\&D expenditure in industry $\mathbf{i}$ is embodied in each type of final output? In an input-output context the first question is typically approached by means of backward multipliers obtained from the input coefficients (Terleckyj 1980). The second question can be answered by means of forward multipliers obtained through the output coefficients. Dietzenbacher and Los (2002) found that these multipliers measure exactly the same phenomenon but from two alternative viewpoints.

From a policy standpoint these two perspectives matter with respect to the question of the side from which $R \& D$ should be stimulated. If the government decides to subsidize $R \& D$ in a certain industry with the aim of gaining a competitive advantage, forward multipliers state how much of each additional Euro invested in R\&D in industry $\mathbf{i}$ ends up in the final demand, e.g. in exports. On the other hand, the government may stimulate R\&D by stimulating additional final demand in particular industries, for instance the automobile industry. In such a case the backward multipliers will pinpoint the industry for which the total effects of R\&D will be the largest. 
In the case of the German R\&D program initiated in reaction to the economic crisis the government has stimulated $R \& D$ in a wide variety of industries. Forward multipliers indicate to what extent the results of R\&D increase final output in the long run. However, in the shortterm the stabilizing macroeconomic effect would remain beyond the analysis and that is exactly where our paper comes in. Our hypothesis is that a supply push induced by R\&D subsidies is accompanied by a demand push because $R \& D$ activities encourage purchases of goods and services as well as labor by the subsidized R\&D companies. This short-term effect will stabilize production and employment during an economic crisis.

\subsection{R\&D in national accounts}

In order to investigate the short-term stabilizing effects of R\&D spending empirically, we use the input-output method which is part of national accounts. Before turning to the input-output model used in this paper, the status of $R \& D$ in national accounts requires some consideration.

Up to now, R\&D in national accounts has been treated as an intermediate product, produced in a private enterprise or a public research entity, provided as an intermediate commodity to other sectors and finally expended in one production circuit. In national accounts, R\&D on the one hand increases the value added for the relevant producer (e.g. enterprise or research institute). On the other hand, in national accounts, R\&D reduces the value added for those producers who use and bear the costs of R\&D. Thus, in the bookkeeping procedures of actual national accounting, R\&D has a positive impact on gross domestic product (GDP) only as far as it contributes to the value added of firms. Only in the case of basic research in the public sector is $R \& D$ expenditure considered in national accounts as a final product which increases the GDP. However, this official treatment of $R \& D$ expenditure as consumable goods in national accounts is not consistent with the nature of R\&D and its understanding in economics (Godin 2007). 
Therefore, based on the Frascati Manual (OECD 2002)1, the United Nations' Statistical Commission recommends in its revision of the system of national accounts the redefining of R\&D as intangible capital goods (European Commission et al. 2009). While the System of National Accounts (SNA) of the UN is not binding, the European System of Accounts (ESA) is mandatory for EU member states. At the European level, since 2010 an intensive discussion including statistical pilot studies for a revision of accounts took place. The EU will change the ESA in September 2014, and among other changes, R\&D will be re-defined as an investment good. That means, R\&D will become a component of the capital stock. Those agents conducting R\&D activities aim to achieve economic benefits by creating and using knowledge not just once but several times in the production process, and in several fields. Transferring this perspective into national accounts would be more in line with the economic nature of R\&D and the idea of cumulative innovation (Antonelli 1997, Malerba 1992, Pavitt et al. 1989). It would allow an increase of GDP during the actual operation of an R\&D project (production phase) and would encourage the production of inputs needed to carry out the R\&D activities by the enterprises.

Against this background, backward multipliers will reflect the stabilizing effect of R\&D expenditure in the short-term. Thus, the paper follows this methodological approach, i.e. we treat $R \& D$ as a component of final demand.

\subsection{The standard open input-output model}

The new definition of R\&D expenditure in national accounts as part of final demand has farreaching consequences when measuring the short-term macroeconomic effects of subsidized $R \& D$ activities. This approach allows for the interpretation of $R \& D$ expenditure as a demand

1 In line with the Frascati Manual (OECD 2002, p. 30), R\&D "comprises creative work undertaken on a systematic basis in order to increase the stock of knowledge and the use of this stock of knowledge to devise new applications". 
push. The push itself extends to both the output and the income generated in the production process as well as the utilization of the additionally generated income. With respect to our subject - stabilization effects from increased R\&D expenditure - the appropriate analytical tool is the open input-output model, also called Leontief model (Miller and Blair 2009). The idea behind fiscal policy tools in an economic crisis is to stimulate demand, in our particular case the demand for domestically produced products necessary to run R\&D projects. Thereby, not only a production effect occurs in firms realizing the R\&D projects, but also in supplier firms as well as suppliers of suppliers and so forth. Through this production, income is generated and spent for consumer goods which in turn induce production in consumer goods industries and their suppliers (see Figure 2). The idea is a big chain reaction which finally runs across all sectors of the economy. For our study we need to find a method that is able to capture the production effects and related employment and value added effects of exactly these processes. A neoclassical production function approach considers primary inputs, i.e. capital, labor, and technology, in order to determine production output (Godin 2007). In contrast, the input-output model takes into account primary as well as intermediate inputs of production. The latter is therefore also called a KLEM production function (KLEM = capital, labor, energy, and material inputs) (Rose 1996).

For input-output analyses, the entire economic activity of a country is separated into a number of producing sectors. Each sector has "a single characteristic activity carried out using the average mix of technology for that sector in a given year." (Duchin and Lange, 1995, 340). Besides the primary input, the input-output model displays the interdependencies between the different sectors of the economy based on their intermediate goods linkages in the sense of direct supplier relations. These linkages are expressed through input coefficients. Using the Leontief inverse of the input coefficients, direct as well as indirect supplier relations can be 
captured (Blair and Miller 2009). In an input-output model every increase in final demand - in our case R\&D as an investment ${ }^{2}$ - results in a certain production (employment, value added) effect in all sectors directly and indirectly related to R\&D activity. Thereby, input-output models assume constant returns to scale, i.e. a fixed amount of each primary and intermediate input is required to produce one unit of output per sector. Furthermore, it assumes nonsubstitutable of inputs which is technically motivated, e.g. in automobile production one cannot replace steering wheels with tires, at least within one period of production.

Summing up, the fact that direct as well as indirect effects can be measured provides an advantage of input-output analyses. Econometric macro models based on a neoclassical production function are typically one-sector models with a high level of aggregation and therefore not precise enough for our subject of analysis.

In our study we differentiate between the effects of the demand push (R\&D) which are expected in the phase running the $R \& D$ projects (production phase), and the effects of the utilization of the additional income generated in this production phase (use of income phase). For basic equations of the standard open input-output model see Table 1.

In the first step we focus on the total direct and indirect effects stemming from subsidized R\&D activities in the production phase. The total output $\boldsymbol{x}$ is measured by multiplying the inverse input coefficients of the open input-output model with the vector of $R \& D$ expenditures $\mathbf{y}^{(1)}$, which constitutes the exogenous variable. The total production output $(\mathrm{x})$ incorporates a certain value added. The value added is calculated through the entry-wise multiplication ${ }^{3}$ of the column vector of $\mathbf{x}^{(1)}$ with a column vector $\mathbf{v}$, whose elements indicate the share of value added to total

2 By definition, only final demand (in our case R\&D investment) has an effect on the GDP. Since R\&D has investment characteristics, and since we re-defined R\&D as an investment (chapter 2.2), we are able to measure short term stabilization effects of $R \& D$ projects.

3 The symbol * used in the equation stands for element by element multiplication, the so-called Hadamard product. 
output by sectors. This way we get the total value added $\mathbf{v a}^{(1)}$ in the production phase as a derived figure. In the same way, the entry-wise multiplication of the vector $\mathbf{x}^{(1)}$ with a column vector $\mathbf{b}$, whose elements indicate the input of the labor force per one million Euros of output, leads to the total employment $\mathbf{l}^{(1)}$ necessary to generate the output (value added) in the production phase (see Figure 2). It is important to notice that we relate all macroeconomic effects (output, value added and employment) to the total primary impulse of R\&D expenditure. The subsidized R\&D projects induce a certain output which corresponds to a certain value added and employment. All effects comprise the direct effects (subsidized firms) as well as the indirect effects (firms linked to subsidized firms as suppliers).

\section{Table 1}

Basic equations $^{\mathrm{a}}$

\begin{tabular}{|l|l|l|l|}
\hline & Production phase & Use-of-income phase & In sum \\
\hline Output & $\mathbf{x}^{(1)}=\left(\mathbf{I}-\mathbf{A}^{\mathrm{d}}\right)^{-1} * \mathbf{y}^{(1)}$ & $\mathbf{x}^{(2)}=\left(\mathbf{I}-\mathbf{A}^{\mathrm{d}}\right)^{-1} * \mathbf{y}^{\mathrm{pc}}$ & $\mathbf{x}=\mathbf{x}^{(1)}+\mathbf{x}^{(2)}$ \\
\hline Value added & $\mathbf{v a}^{(1)}=\mathbf{x}^{(1)} \cdot * \mathbf{v}$ & $\mathbf{v a} \mathbf{a}^{(2)}=\mathbf{x}^{(2)} \cdot * \mathbf{v}$ & $\mathbf{v a}=\mathbf{v a} \mathbf{a}^{(1)}+\mathbf{v a}^{(2)}$ \\
\hline Employment & $\mathbf{I}^{(1)}=\mathbf{x}^{(1)} \cdot * \mathbf{b}$ & $\mathbf{I}^{(2)}=\mathbf{x}^{(2)} \cdot * \mathbf{b}$ & $\mathbf{I}=\mathbf{l}^{(1)}+\mathbf{I}^{(2)}$ \\
\hline
\end{tabular}

${ }^{\mathrm{a}}$ The superscript ${ }^{(1)}$ stands for the production phase, ${ }^{(2)}$ for the use-of-income phase.

The notations mean:

$\mathbf{x} \quad$ vector of induced total output by sectors (measured in million Euros);

I identity matrix;

$\mathbf{A}^{\mathrm{d}} \quad$ matrix of coefficients showing the direct input of intermediate goods produced domestically per unit of gross output;

$\mathbf{y}^{(1)} \quad$ R\&D expenditure split between the purchase of material and immaterial capital goods reported in different final demand categories;

$\mathbf{y}^{(\mathrm{pc})}$ private consumption stimulated by the extra income (measured in million Euros);

va vector of induced value added by sectors (measured in million Euros);

$\mathbf{v} \quad$ vector whose elements indicate the share of value added in gross output by sectors;

I vector of induced employment by sectors (measured in 1000 persons); 
b vector whose elements indicate the input of the labour force per one million Euros of gross output.

In the second step (use-of-income phase), we include macroeconomic effects caused by the use of additional income of employees active in the production phase. Persons directly or indirectly employed in the production process, running $R \& D$ projects, use part of their income to purchase consumer goods. Hence, through the circular flow of income, further production is stimulated and jobs are secured or even newly created. However, the gross income earned in the production phase cannot all be spent on consumption by private households (see Figure 2). It is reduced by taxes, contributions to the social security system, savings etc. ${ }^{4}$ Here it is presumed that the components of additional private consumption $\mathbf{y}^{(\mathrm{pc})}$ correspond to the average composition of private consumption according to the national input-output data. From a theoretical perspective, this is in line with the permanent income hypothesis (Friedman 1957) which implies that consumers maintain their consumption behavior over the business cycle. Therefore, we assume a typical basket of goods here. Other input-output studies typically rely on this approach too (e.g. Hujer and Kokot 2001). Moreover, the consumption expenditure is split between the purchase of domestic and imported goods. As imports do not stimulate additional production in the home country, their share in the total expenditure on consumable goods is excluded. The "gains" to value added $\mathbf{v a} \mathbf{a}^{(2)}$ and employment $\mathbf{l}^{(2)}$ corresponding to $\mathbf{x}^{(2)}$ arise from the entry-wise multiplication with the vectors $\mathbf{v}$ and $\mathbf{b}$ respectively. Thus, the calculation approach as such is the same in the production phase and the use of income phase. The total macroeconomic effects

4 In the following only the second round effects are considered. In other words, the production, employment and income effects of the income induced employment $\mathbf{l}^{(2)}$ etc. are ignored. 
calculated through the input-output method are all traced back to the primary impulse of R\&D spending.

The total output effect produced by the R\&D subsidies in both phases is given by the sum of $\mathbf{x}^{(1)}$ and $\mathbf{x}^{(2)}$. The total effects on value added and employment in both phases are calculated in a similar way. Finally, the results of the input-output model provide the empirical basis for the estimation of backward multipliers which capture the impact of the impulse via supplier linkages in the national economy (Figure 2 provides an illustration of the research design). For example, the output multiplier $\mathrm{M}(\mathrm{x})$ concerning both phases is calculated as follows, where $\mathbf{i}$ indicates a row unit vector:

$\mathrm{M}(\mathrm{x})=\mathbf{i}^{*}\left(\mathbf{x}^{(1)}+\mathbf{x}^{(2)}\right) / \mathbf{i}^{*} \mathbf{y}^{(1)}$ 


\section{Figure 2}

Production Phase and Use-of-Income Phase

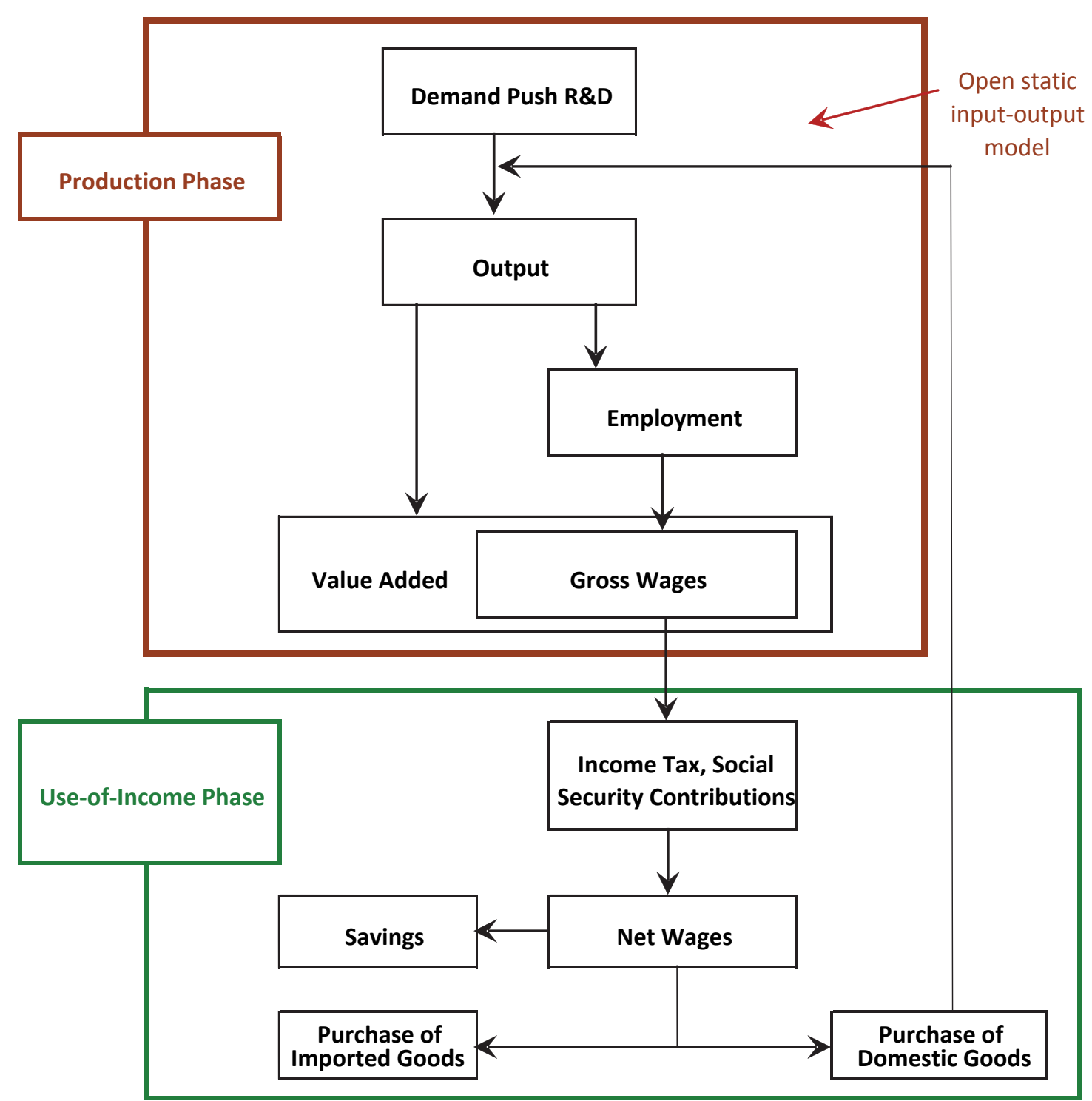

Source: Authors' illustration.

In order to measure the macroeconomic impact of the R\&D program we have used the official German input-output tables for the year 2007, the year before the economic crisis. . At the beginning of the crisis it was the only available database for ex-ante estimates of economic effects of R\&D subsidies. Later on input-output tables of the year in the crisis (2009) can be used to control for these effects. However, this approach meets some specific challenges as the 
input output coefficients of an "extraordinary" year reflect a variety of different impacts, and it is difficult to split up these impacts on estimation results.

Sectors of the input-output table are classified by homogenous production sectors, not by industries comparable to NACE classification. R\&D activities in the input-output tables build one production sector regardless of the industry in which R\&D is conducted. SMEs usually engage in $R \& D$ activities as a secondary business. For the purposes of our analysis we assume that R\&D in SMEs follows the same structural logic as in specialized R\&D units. Thus, in our empirical study the financial impulse of the R\&D program will be passed on to the national economy solely via the interactions of the production sector "Research and development services". We use input coefficients for domestic production in order to capture the effects of $R \& D$ spending on the demand of domestically produced inputs for running $R \& D$ projects.

\section{Data on R\&D subsidies}

The German "Central Innovation Program for SMEs" (ZIM) on which we focus in our study offers funding for R\&D projects conducted by SMEs with up to 250 employees. SMEs undertake the projects either alone (ZIM SOLO) or in cooperation with other enterprises or public research organizations (ZIM KOOP). If they cooperate with other enterprises, these enterprises of course have to qualify as SMEs according to the program regulations if they want to get funding. The Federal Ministry of Economics and Technology launched this program in July 2008 regardless of the economic crisis. It started with a call for proposals for ZIM-KOOP projects in July 2008 and a call for proposals for ZIM-SOLO projects in January 2009. The first ZIM-KOOP projects started in the last quarter of the year 2008, further projects in both lines followed successively.

ZIM was initiated in the year 2008, but it was an update of existing programs. Thus, SMEs in Germany were familiar with application procedures. Accordingly, the time to apply for funding 
took one to 30 days (median: 10 days) for the beneficiaries in the ZIM program (Kulicke at al. 2010). This is clearly below other comparable R\&D support schemes in Germany (Günther et al. 2010, 93ff and Günther et al. 2008, 115f). This was in favor of more rapid effects during the economic crisis.

Beneficiaries are private SMEs running individual $R \& D$ projects and, in the case of cooperative projects also include public research institutes and universities. SMEs with up to 250 employees are eligible for 35 to 50 percent of their total R\&D costs while larger mid-sized firms with up to 1000 employees can get refinanced 25 to $35 \%$ of their total $R \& D$ costs. The exact rate depends on the program line (ZIM SOLO or ZIM KOOP) and the location of the firm (Eastern or Western Germany). The funding is not allowed to exceed 350000 Euros. Research organizations can claim back 90 to 100 percent of their R\&D costs. The maximum grant for cooperation projects is two million Euros. Enterprises and research organizations apply for $\mathrm{R} \& \mathrm{D}$ funding at one of the program management agencies in charge. The program is open to any technological field or industry; only projects with a feasible business plan and innovative ideas are subject to the selection process, however.

In reaction to the global economic crisis the budget of the R\&D program was substantially increased for the years 2009 and 2010.5 In addition to the originally approved basic budget of 626 million, the government approved a further 900 million Euros. This extra budget formed one component of the overall stabilization program in Germany. Firms could apply for project funding within the stabilization program from February 2009 after the European Commission had authorized the program in an accelerated approval procedure on February 13, 2009. This was important because the deep recession called for quick procedures. Selection procedures

5 Once approved, projects may extend beyond 2010. The maximum duration of R\&D projects within ZIM is three years. 
lasted about four months 6 so that first projects supported within the stabilization program started from mid 2009. By the end of the year 2009, 450 million Euros arrived in SMEs to be used for R\&D activities.

With the authorization of the extra budget, the scope regarding companies was extended and enterprises with up to 1000 employees became eligible. But according to the understanding of the German government and policy makers involved, the program predominantly remained an SME support scheme. Big corporations were excluded. The firms with up to 1000 employees were referred to as "larger mid-sized firms". ZIM SOLO, originally restricted to SMEs in Eastern Germany, was opened up to SMEs and "larger mid-sized firms" located in Western Germany. Overall, it was the intention to reach a larger group of firms in order to quicker distribute the extra budget and stabilize the economy.

\section{Figure 3}

Granted R\&D subsidies as of January/February 2011 (in million Euros)

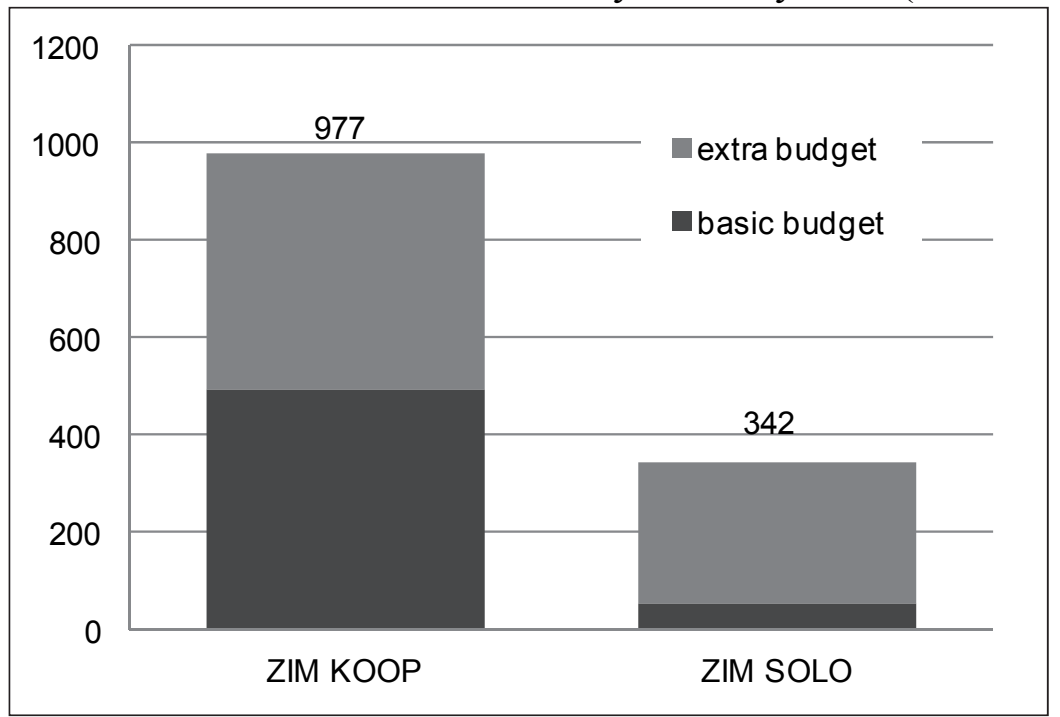

Source: Federal Ministry of Economics and Technology, authors' illustration.

According to Figure 3, R\&D projects carried out in cooperation with other enterprises or research organizations (ZIM KOOP) were funded to the amount of 977 million Euros

6 This is comparable to other R\&D support programs (Günther et al. 2008, 118). It shows that the increased number of applications through the ZIM extra budget did not cause additional time lags. 
(representing 75 percent of all means), whereas the total support for individual projects (ZIM SOLO) amounted to 342 million Euros (representing 24 percent of the total means). As of January 2011, the total number of approved applications amounted to 13,291 for the years 2009 and 2010. Thereby, the number of firms supported increased strongly, especially with respect to ZIM SOLO. The budget increase led to 4,237 additional R\&D projects through the extra budget as compared to 924 projects granted within the basic budget. Collaborative R\&D projects also increased from originally 4,271 selected projects within the basic budget to a total of 8,130 through the extra budget among them, 2,710 applied for by research organizations and 5,420 by private firms.

As regards the size of firms "lager mid-sized firms" with up to 1000 employees accounted for $12 \%$ of all firms participating in the program lines ZIM SOLO and ZIM KOOP (Depner et al. 2011). Thus, the characteristic of an SME program was kept.

In order to investigate the macroeconomic effects of the R\&D program, the primary financial impulse must first be determined, i.e. the total sum of R\&D expenditure consisting of the public subsidies plus private funds additionally stimulated by the R\&D program. According to the legal framework of the $R \& D$ program, a large share of $R \& D$ expenditure must be covered by the SMEs themselves. In January 2011, the sum of R\&D subsidies amounted to 1.3 billion Euros. 7 Together with the private co-financing of the SMEs (and partially by research organizations) the total volume spent on R\&D activities amounted to 3.7 billion Euros. This is 2.8 times the sum of the initial public funding. This sum of 3.7 billion is the primary impulse expected to contribute to a stabilization of demand and thus production and employment during the crisis.

7 Data on subsidized R\&D projects was provided by the project management agencies acting on behalf of the Federal Ministry of Economics and Technology. We thank the Ministry and the project management agencies for the data provision and friendly support. 
In investigating the macroeconomic stabilization effects, it is necessary to identify the transmission channels and the extent of final demand brought about by the R\&D program. It is also important to identify which economic agents (e.g. enterprises or private non-profit organizations) received the stimulus. Being itself interpreted as immaterial capital goods it can be assumed that the processing of $R \& D$ requires the purchase of both capital goods (e.g. machinery, equipment, software) as well as intermediate goods (e.g. raw materials, fuel, chemicals, services etc.). These purchases correspond to transmission channels affecting various sectors and have a different impact on the economy as a whole.

\section{Table 2}

R\&D primary impulse for the years 2009 to 2011

- in million Euros, as of January/February 2011 -

\begin{tabular}{|c|c|c|c|}
\hline & $\begin{array}{l}\text { ZIM } \\
\text { Basic budget }\end{array}$ & $\begin{array}{l}\text { ZIM } \\
\text { Extra budget }\end{array}$ & $\begin{array}{l}\text { ZIM } \\
\text { Total }\end{array}$ \\
\hline R\&D primary impulse, total & 1493.9 & 2.235 .1 & 3728.1 \\
\hline \multicolumn{4}{|l|}{ Thereof, purchases of: } \\
\hline capital goods & 212.5 & 306.6 & 519.2 \\
\hline intermediate goods & 1280.4 & 1928.5 & 3208.9 \\
\hline
\end{tabular}

Source: Federal Ministry of Economics and Technology, authors' calculations.

The total R\&D expenditure of 3.7 billion Euros is split between the purchase of capital goods and of intermediate goods since they induce production and related value added as well as employment in different areas of the economy with quantitatively different macro effects. In order to disentangle our figures on R\&D spending between capital goods and intermediate goods we use a scheme developed within a Eurostat project. This has been applied to convert German R\&D statistics into categories of national accounts by the German Federal Statistical Office Oltmanns et al. (2009). This conversion scheme was developed to prepare for the revision of national accounts. It constitutes a reference scheme to convert official R\&D statistics (Frascati Manual) into the classification of National Accounts, which is suitable for input output analyses. In this context and based on official R\&D statistics for Germany in the year 2003, 
Oltmanns et al. (2009) show for each industrial sector how much of the R\&D spending is devoted to the purchase of capital goods for $\mathrm{R} \& \mathrm{D}$ projects. 8 The rest is $\mathrm{R} \& \mathrm{D}$ spending on intermediate goods. We use the reference scheme of Oltmanns et al. (2009) in order to appropriately disentangle the ZIM data on R\&D spending, which for our study is only available as total $\mathrm{R} \& \mathrm{D}$ spending by industries.

As a result, the lion's share of $R \& D$ expenditure applies to the purchase of intermediate goods, with 3.2 billion Euros or 86 percent of the total primary impulse (Table 2). The amount of R\&D spending dedicated to the purchase of capital goods accounts for only 0.5 billion Euros or 14 percent of the total primary impulse. This differentiation is crucial for a proper determination of the overall macroeconomic effects.

For the purposes of empirical analysis, the two categories, capital goods ( 0.519 billion Euros) and intermediate goods ( 3.2 billion Euros), now need to be ascribed to the relevant and effective sectors of the economy in the context of input-output tables.

The sectors from which enterprises typically purchase capital goods were identified through the cross investment matrix provided by the Federal Statistical Office. With regard to the R\&D spending on intermediate goods, we assume that R\&D in SMEs follows a pattern comparable to actors specialized in R\&D activities (see chapter 2). Thus, the sum of the purchased intermediate goods is attributed to the sector "Research and Development" in the input-output context.

8 Thereby, Oltmanns et al. (2009) use information from an additional datasource, the socalled "cost structure survey" of the German statistical office. The conversion was done using R\&D statistics for the year 2003. More recent empirical calculations that could be used as a reference scheme are not available. We assume that in the aggregate the share of R\&D spending devoted to capital goods has not changed substantially. 


\section{Results}

R\&D projects generated by the German R\&D program ZIM are expected to stabilize economic output in a crisis and to secure or increase employment. Not only are immediate beneficiaries of the R\&D program affected; indirect effects also occur, especially through the actions of suppliers linked to beneficiaries of the R\&D program. We can measure both direct and indirect effects on output, value added and employment using the input-output model as described above. First, the direct and indirect effects occur during the stage at which the R\&D projects are conducted (production phase). Subsequently, employees spend a portion of their income on consumption, which in turn increases output, value added and employment in the relevant consumer goods industries (use-of-income phase). Accordingly, we differentiate between the effects of the production phase and those of the use-of-income phase, the "phase specific effects", as well as the overall effect which is the sum of both phases. In the following section, the macroeconomic effects are determined for the two categories of goods purchased by the beneficiaries of ZIM, capital goods and intermediate goods.

\subsection{Direct and indirect effects of $R \& D$ spending on capital goods}

As indicated above, SMEs and research organizations use some of their financial means to purchase new machinery, equipment or software for running R\&D projects. Approximately 14 percent of the original primary impulse is used for the purchase of capital goods (see chapter 3). Between the years 2009 and 2011 the total production effect of these investments made up 882 million Euros which represents an added value of 361 million Euros (see Table 3). 
Table 3

Total effects of R\&D spending by ZIM for the purchase of capital goods - in million Euros -

\begin{tabular}{|c|c|c|c|c|}
\hline & 2009 & 2010 & 2011 & Total \\
\hline \multicolumn{5}{|l|}{ Output effect } \\
\hline Production phase & 102.8 & 346.7 & 432.8 & 882.3 \\
\hline Use-of-income phase & 17.7 & 59.4 & 74.4 & 151.5 \\
\hline Sum & 120.5 & 406.1 & 507.3 & 1033.8 \\
\hline Share of the production phase in $\%$ & 85.3 & 85.4 & 85.3 & 85.3 \\
\hline \multicolumn{5}{|l|}{ Value added effect } \\
\hline Production phase & 42.1 & 141.5 & 177.4 & 361.0 \\
\hline Use-of-income phase & 9.3 & 31.2 & 39.1 & 79.6 \\
\hline Sum & 51.4 & 172.8 & 216.5 & 440.7 \\
\hline Share of the production phase in $\%$ & 81.9 & 81.9 & 81.9 & 81.9 \\
\hline \multicolumn{5}{|l|}{ Employment effect (in 1000 persons) } \\
\hline Production phase & 0.6 & 2.2 & 2.7 & 5.5 \\
\hline Use-of-income phase & 0.2 & 0.6 & 0.7 & 1.5 \\
\hline Sum & 0.8 & 2.7 & 3.4 & 7.0 \\
\hline Share of the production phase in $\%$ & 79.1 & 79.0 & 79.0 & 79.0 \\
\hline \multicolumn{5}{|l|}{ Income effect } \\
\hline Production phase & 27.0 & 90.8 & 113.7 & 231.5 \\
\hline Use-of-income phase & 4.7 & 15.7 & 19.7 & 40.2 \\
\hline Sum & 31.7 & 106.5 & 133.4 & 271.6 \\
\hline Share of the production phase in $\%$ & 85.2 & 85.2 & 85.2 & 85.2 \\
\hline
\end{tabular}

Source: Authors' calculations.

In addition, the production of capital goods secured or created approximately 5500 jobs. The spending of income by these employees in turn increased production, employment and income in consumer goods industries as well as in the directly and indirectly linked supplier industries. The production effect in the use-of-income phase amounted to 152 million Euros which translates as an added value of 80 million Euros. Furthermore, 1500 jobs were secured or newly created in the consumer goods industries. To sum up, the share of the production phase made up to approximately 80 to $85 \%$ of the total effects. The multipliers which describe the relationship between the primary impulse and the total effect amount to 2 to 2.4 (see Table 4 ). 


\section{Table 4}

Multipliers of the primary impulse from the purchase of capital goods

\begin{tabular}{|l|lll|l|}
\hline \multirow{2}{*}{} & \multicolumn{4}{l}{ Total effect in relation to primary impulse } \\
\cline { 2 - 5 } & 2009 & 2010 & 2011 & Total \\
\hline Output & 2.0 & 2.0 & 2.0 & 2.0 \\
Value added & 2.2 & 2.3 & 2.3 & 2.3 \\
Employment & 2.4 & 2.4 & 2.4 & 2.4 \\
Income & 2.0 & 2.0 & 2.0 & 2.0 \\
\hline
\end{tabular}

Source: Authors' calculations.

\subsection{Direct and indirect effects of R\&D spending on intermediate goods}

The largest share of the primary impulse -86 percent of the total or 3.2 billion Euros - is used for the purchase of intermediate goods (see chapter 3 ). The purchase of intermediate goods for $R \& D$ projects stimulates production via supplier linkages in the same way as expenditure on capital goods. Yet, it must be taken into consideration that different sectors of the economy benefit from the purchase of intermediate goods. The total output effect of spending on intermediate goods amounts to 5315 million Euros (see Table 5). 


\section{Table 5}

Total effects of R\&D spending by ZIM for the purchase of intermediate goods - in million Euros -

\begin{tabular}{|c|c|c|c|c|}
\hline Output effect & 2009 & 2010 & 2011 & Total \\
\hline Production phase & 592.8 & 2110.3 & 2611.9 & 5314.9 \\
\hline Use-of-income phase & 150.9 & 537.2 & 664.9 & 1353.0 \\
\hline Sum & 743.7 & 2647.5 & 3276.8 & 6668.0 \\
\hline Share of the production phase in $\%$ & 79.7 & 79.7 & 79.7 & 79.7 \\
\hline \multicolumn{5}{|l|}{ Value added effect } \\
\hline Production phase & 302.8 & 1077.8 & 1334.0 & 2714.6 \\
\hline Use-of-income phase & 79.3 & 282.4 & 349.5 & 711.1 \\
\hline Sum & 382.1 & 1360.2 & 1683.5 & 3425.8 \\
\hline Share of the production phase in $\%$ & 79.2 & 79.2 & 79.2 & 79.2 \\
\hline \multicolumn{5}{|l|}{ Employment effect (in 1000 persons) } \\
\hline Production phase & 5.5 & 19.6 & 24.3 & 49.4 \\
\hline Use-of-income phase & 1.5 & 5.2 & 6.4 & 13.1 \\
\hline Sum & 7.0 & 24.8 & 30.7 & 62.5 \\
\hline Share of the production phase in $\%$ & 79.0 & 79.0 & 79.0 & 79.0 \\
\hline \multicolumn{5}{|l|}{ Income effect } \\
\hline Production phase & 230.5 & 820.7 & 1015.8 & 2067.0 \\
\hline Use-of-income phase & 40.0 & 142.4 & 176.2 & 358.7 \\
\hline Sum & 270.5 & 963.1 & 1192.0 & 2425.7 \\
\hline Share of the production phase in $\%$ & 85.2 & 85.2 & 85.2 & 85.2 \\
\hline
\end{tabular}

Source: Authors' calculations.

In the context of purchases of intermediate goods, nearly 50000 employees benefit from the expanded production, ten times the employment effect stemming from the purchase of capital goods (see Table 5). The increase in output corresponds to an increase in value added amounting to 2715 million Euros. This leads to 2067 million Euros in income for employees. The total effect of the primary impulse on the four indicators is shown in Table 6.

Again, private households spend part of their additional income on consumer goods. This in turn increases production, employment and income in consumer goods industries and the directly and indirectly linked supplier industries. The production effect in the use-of-income phase amounts to 1353 million Euros, again nearly ten times the effect observed for the 
purchase of capital goods for $R \& D$ projects. Yet, the share of the production phase in the total effects amounts to 80 percent, similar to the observations for the expenditure on capital goods.

Table 6

Multipliers of the primary impulse from the purchase of intermediate goods

\begin{tabular}{|l|lll|l|}
\hline \multirow{2}{*}{ Output } & \multicolumn{5}{|l|}{ Total effect in relation to primary impulse } \\
\cline { 2 - 6 } & 2009 & 2010 & 2011 & Total \\
Value added & 2.1 & 2.1 & 2.1 & 2.1 \\
Employment & 2.4 & 2.4 & 2.4 & 2.4 \\
Income & 2.4 & 2.4 & 2.4 & 2.4 \\
\hline
\end{tabular}

Source: Authors' calculations.

\subsection{Overall effects of the R\&D program}

To sum up, the initial funding of the subsidized R\&D program results in an output, value added and employment effect that amounts to at least twice the initial funding. This is indicated by the multipliers presented in Table 8, all of which are above two. The activities of the production phase are most strongly effective. They account for 80 percent of the total effect. Over the years 2009 to 2011, an additional, cumulative production of 7.7 billion Euros results, which includes a value added of 3.9 billion (see Table 7). Furthermore, up to 69500 jobs were secured or newly created, with a total income of 2.7 billion Euros.

\section{Table 7}

Overall effects from the purchase of capital and intermediate goods (production phase plus use-of-income phase)

- in million Euros -

\begin{tabular}{|l|l|l|l|l|}
\hline & 2009 & 2010 & 2011 & Total \\
\hline Primary impulse & 418.5 & 1478.2 & 1831.4 & 3728.1 \\
\hline Ouput & 864.1 & 3053.6 & 3784.1 & 7701.8 \\
Value added & 433.5 & 1533.0 & 1900.0 & 3866.4 \\
Employment (1 000 persons) & 7.8 & 27.5 & 34.1 & 69.5 \\
Income & 302.2 & 1069.6 & 1325.4 & 2697.3 \\
\hline
\end{tabular}

Source: Authors' calculations. 


\section{Table 8}

Overall multipliers from the purchase of capital and intermediate goods ${ }^{\mathrm{a}}$ (production phase plus use-of-income phase)

\begin{tabular}{|l|l|l|l|l|}
\hline & 2009 & 2010 & 2011 & Total \\
\hline Ouput & 2.1 & 2.1 & 2.1 & 2.1 \\
Value added & 2.3 & 2.3 & 2.3 & 2.3 \\
Employment (1 000 persons) & 2.4 & 2.4 & 2.4 & 2.4 \\
Income & 2.0 & 2.0 & 2.0 & 2.0 \\
\hline
\end{tabular}

${ }^{a}$ Overall effect in relation to the primary impulse.

Source: Authors' calculations.

Compared to the downswing of the German economy during the economic crisis, the stabilizing effect of the R\&D program ZIM seems to be relatively small. However, it prevented a decline of GDP by about 0.5 percent in the most critical year of the economic crisis, 2009. Moreover, it has generally stabilized the enterprises' expectations and counteracted the vulnerability of production and employment in SMEs. In the following two years it contributed to the growth of GDP, by 1.5 percent in 2010 and 2.2 percent in 2011 as a share in the absolute increase of GDP.

Despite the difficulties using input output coefficients of "extraordinary" years for the purpose of our paper (see chapter 2.3), we run a robustness check with data comparing the years 2008 and 2009, which were compiled by the German Federal Statistical Office in the same conceptual manner. 9 The main results of this ex-post examination are: If the coefficient matrix of the "extraordinary" year 2009 is used in the model, the multipliers differ compared to the year before the crisis (2008). In sum, the output multiplier hardly changes whereas the multipliers of value added, employment and income sink by about three to five per cent. To what extent

9 After the year 2007, in the countries of the EU the conceptual framework of the national accounts (incl. the compilation of input-output tables) was changed through an official revision. This heavily restricts the comparability of results between the year 2007 and all later years as revisions especially refer to the classification of the R\&D sector. Therefore, we provide the robustness check with data comparing the years 2008 and 2009, which were compiled by the German Federal Statistical Office in the same conceptual manner. 
these changes can be attributed to statistical reasons or to the impact of policy measures against the economic crisis cannot be further disentangled here. Overall, in an ex-post framework of analysis, production effects would hardly differ while the value added, employment, and income effects might be slightly overestimated.

\subsection{Alternative use of subsidies}

Finally, our results raise the question of the macroeconomic effects in the case of an alternative use of public money. Fiscal policy measures used during the economic crisis covered a variety of applications. The R\&D program which can be added to investments in infrastructure was only one type of measure. There is much proof that public investment in infrastructure leads to the highest multipliers (Heppke-Falk et al. 2006; Romp and de Haan 2007). But limits due to absorptive capacity can occur which call for a variety of stabilization schemes. Other measures, for example, aimed to relieve the regulations of short time work or to increase private consumption via tax cuts, vouchers or allowances for buying a new car. Thus, one could argue that a direct subsidization of private consumption would also have been effective as a means of stabilization. In fact, in Germany there were also means within the fiscal policy program to subsidize consumption. Some of them were directly supporting private consumption, such as the grants for buying a new automobile. A number of other means indirectly supported private consumption through income tax reductions, automobile tax relief for new cars, allowances for tax payers with children, allowances for employees commuting to their workplace etc. These means were aimed to stimulate the consumption of private households, but one cannot exactly determine how much extra demand was created due to these tax reliefs and allowances. Therefore, we cannot directly contrast the effects of R\&D subsidization (ZIM) with the effects due to the stimulation of private consumption. Our scenario calculation (simulation) therefore 
answers the question of what had happened if the primary impulse in the amount of 3.2 billion Euro would have been directed into consumption as an alternative use.

Table 9: Total effects of R\&D spending by ZIM $\mathrm{M}^{\mathrm{a}}$ and alternative use of public funds (private consumption)

\begin{tabular}{|l|c|c|c|}
\hline & $\begin{array}{c}\text { R\&D spending } \\
\text { by ZIM }\end{array}$ & Alternative use & R\&D projects = 100 \\
\hline Total effect & 6668.0 & 5486.8 & 82 \\
Output & 3425.8 & 2897.1 & 85 \\
Value added & 62.5 & 53.3 & 85 \\
Employment (1000 Persons) & 2425.7 & 1458.1 & 60 \\
Income & & & 82 \\
\hline Multiplier & 2.1 & 1.7 & 78 \\
Output & 2.4 & 1.8 & 70 \\
Value added & 2.4 & 1.7 & 93 \\
Employment & 2.0 & 1.9 & \\
Income & &
\end{tabular}

${ }^{a}$ Without purchases of capital goods (compare chapter 4.2).

Source: Authors' calculation.

To make the scenario calculation comparable we used the input-output method as described above (chapter 2.3). Different from above, we introduced the primary impulse into typical consumption good purchases instead of R\&D purchases. We assume a primary impulse of the same size (3.2 billion Euro). The underlying idea is that the purchase of consumption goods stimulates production in sectors different from $R \& D$ purchases and thus leads to different macroeconomic effects. As a result, the effects on output, value added and employment are lower when the money is used for consumption as compared to R\&D. Also the multipliers are smaller in this scenario (see Table 9). 


\section{Discussion and Conclusions}

As a rule, $R \& D$ subsidies raise the question of windfall gains and possible crowding out effects. The question is whether public funding stimulates additional private spending or crowds out private activities. In general, and independent of the type of subsidy, windfall gains can never be completely excluded. Empirical studies, typically those using micro data and matching techniques, provide mixed results on the issue (Aerts and Schmidt 2008; Czarnitzki et al. 2011; David et al. 2000; González and Pazó 2008). But in our context we need to discuss the effective use of public money spent in the specific circumstances of an economic crisis when governments decide to counteract the overall economic crash.

During the economic crisis of 2008 only a few firms were able to increase their R\&D expenditure; the majority had to reduce their R\&D budgets considerably (Archibugi et al. 2013, Archibugi and Filipetti 2011). In Germany, SMEs and larger mid-sized firms constitute an important segment of the economy, and of technology intensive industries. A shortfall or disruption of R\&D projects would have had negative consequences during the time of crisis and beyond. A survey among beneficiaries of the R\&D program ZIM found that without public funding, the vast majority of firms would have been forced to cancel or postpone their R\&D projects or to downsize them as a result of the crisis (Kulicke et al. 2010). In this regard, the $R \& D$ programs had a stabilizing effect on demand in general and $R \& D$ in particular. In other words, R\&D subsidization takes primarily the function of fiscal policy, which later on also unfolds technological progress. Our analysis deals solely with the short term stabilization effects, not with the long term growth effects that will later on derive from the innovations. The latter would focus on the supply side of R\&D projects, i.e. the introduction of new products or processes to be applied in domestic production processes as well as abroad. The supply side, does of course exist, but only in the long run and not as a part of quick stabilization policy. 
In single cases, crowding out effects and thus an overestimation of macroeconomic effects cannot be excluded, but in a deep recession with negative growth and strong pessimism crowding out is less problematic. The crucial question for policy makers during an economic crisis is the timing of fiscal policy schemes. When should the state authorities intervene and when should the state authorities retreat from stabilization activities? Depending on the type of stabilization measures, fiscal policy programs become effective only with a (strong) time lag. Then there is a risk that fiscal policy schemes are still in place when the crisis is already overcome. We do face this problem here as well. But as compared to other stabilization measures, the ZIM program, allowed a comparatively quick realization so that extra demand became effective promptly. A legal framework, awareness of the program, familiarity with application procedures as well as administrative infrastructure already existed. This accelerated the stimulation of macroeconomic production and employment effects as compared for example to large construction and infrastructure programs, which require much more time for official approval procedures, planning and realization.

The German government intended to stabilize the economy and to prevent large scale unemployment by using different measures of the fiscal policy program. The employment effects determined above are substantial, and in fact large scale unemployment did not materialize during the economic crisis in Germany. There is evidence that the R\&D program contributed to this situation. But when looking at the figures - 69500 newly created or secured jobs - one must keep in mind that not all extra employees came out of unemployment or had no income before this. For this reason we calculate an upper limit or maximum income effect. If we assume a minimum income before newly created employment, effects decrease between nine percent (income) and 12 percent (value added) but multipliers remain close to or above two. 
Another limitation of the analysis lies in the assumption that firms and research organisations spend the money for R\&D projects when the public agency in charge pays out the funding. This assumption was needed in order to assign the primary effect (3.7 billion) to the years 2009 , 2010 and 2011. The pay out date is a precisely documented information throughout all projects. But we have reason to believe that in practice the firms and research organisations make advance payments and claim back the R\&D costs afterwards. In our context this means that the real stabilizing effects are higher in the respective years. On the other hand, when looking at the size of the annual effects, we have to be aware that the use of income phase at least for some part becomes effective only with a time lag.

As described above, the big advantage of the input-output method is that we are able to analyse direct and indirect macroeconomic effects stimulated by a certain primary impulse (R\&D expenditure). Thereby, the general limitation is that input-output models do not account for price effects and financial feedbacks (Grady and Muller 1988). Macroeconomic feedback mechanisms can only be captured through macroeconometric models which in turn are unable to account for indirect effects and treat every increase in demand within one sector. Like others focusing on a particular sector, we have decided to use a structural approach (input-output) (e.g. Katz et al. 2010). Macro models are more suitable for evaluating the overall effects of a complete stabilization package where volumes are much higher and the sectoral disaggregation is out of interest here.

In this paper we have realized the idea that $R \& D$ is not a commodity as it is still treated statistically in national accounts. We employed a technique that is more in line with the nature of $R \& D$, namely that it is an investment which already generates economic effects (outcome, value added, employment) at the moment of running the $R \& D$ project. But the stabilizing shortterm effects derived from R\&D activities - subject to our analysis - are only one part of the 
picture. In addition, R\&D activities imply long-term effects - not subject to our analysis - i.e. an important contribution to growth as well as to the national and international competitiveness of the enterprises.

As far as policy issues are concerned, our analysis shows the dilemma between the unexpectedness of an economic crisis and the (unavoidable) time lag before government action. Decisions on whether or not to use fiscal policy, how to design programs, running the application and selection process etc. takes valuable time, time in which the economic crisis deepens. In fact, the R\&D program ZIM was introduced in mid-2008 anyway so that a functioning program structure already existed. The additional budget and widening of the program were realized as quickly as possible within the program infrastructure. The first projects started in the second half of 2008, running for two to three years. Additional projects financed through the fiscal policy scheme against the crisis became real already in the second half of the year 2009. Projects approved in late 2009 and 2010, often running until 2011, no longer had to contend with the economic crisis. As we demonstrated above, the R\&D program counteracted the economic decline in Germany in the year 2009, but by the years 2010 and 2011 it coincided with the recovery of the German economy. However, as compared to investments into new buildings and infrastructure, which require construction permissions, architectural planning etc. before realization, R\&D projects once approved could start immediately.

Further research calls for a comparative analysis of the macroeconomic effects stemming from R\&D programs before, during, and after the economic crisis. This would require the availability of further R\&D subsidization data. Another direction of research would tie in with the literature on R\&D cyclicality more generally (e.g. Aghion et al. 2012, Archibugi et al. 2013, Barlevy 
2007, Shleifer 1986). A comparison of input coefficients before, during and after the economic crisis would allow insight to what extend R\&D follows a cyclical development. 


\section{ACKNOWLEDGEMENTS}

We gratefully acknowledge the provision of unique data from the Federal Ministry of Economics and Technology (BMWi) in Germany as well as the three agencies in charge of the program administration. We further thank participants at the BMWi workshop in Berlin in May 2011 for comments and suggestions particularly related to data and methodology. 


\section{REFERENCES}

Aerts, K., Schmidt, T., 2008. Two for the price of one?: Additionality effects of R\&D subsidies: A comparison between Flanders and Germany. Research Policy 37, 806-822.

Aghion, P.; Askenazy, P.; Berman, N.; Cette, G.; Eymard, L. (2012) Credit Constraints and the Cyclicality of R\&D Investment: Evidence from France, Journal of the European Economic Association, 10 (5), 1001-1024.

Alecke, B.; Mitze, T.; Reinkowski, J. and G. Untiedt (2012): Does Firm Size make a Difference? Analysing the Effectiveness of R\&D Subsidies in East Germany, German Economic Review, 13: 174-195.

Antonelli, C. 1997. The economics of path-dependence in industrial organisation. International Journal of Industrial Organisation 15 (6), 643-675.

Archibugi, D.; Filippetti, A. 2011. Is the Economic Crisis Impairing Convergence in Innovation Performance across Europe? Journal of Common Market Studies, 49, 1153-1182.

Archibugi, D., Filippetti, A., Frenz, M., 2013. Economic crisis and innovation: Is destruction prevailing over accumulation? Research Policy 42, 303-314. Barlevy, G. (2007): On the Cyclicality of Research and Development, American Economic Review, 97, 1131-1164.

Busom, I. (2000): An empirical evaluation of the effects of R\&D subsidies, Economics of Innovation and New Technology, 9, 111-148.

Czarnitzki, D., Hanel, P., Rosa, J.M., 2011. Evaluating the impact of R\&D tax credits on innovation: A microeconometric study on Canadian firms. Research Policy 40, 217 - 229.

Czarnitzki, D., Hottenrott, H., 2011. R\&D Investment and Financing Constraints of Small and Medium-Sized Firms. Small Business Economics 36, 65 - 83.

David, P.A., Hall, B.H., Toole, A.A., 2000. Is public R\&D a complement or substitute for private R\&D? A review of the econometric evidence. Research Policy 29, 497-529.

Depner, H., Gorynia-Pfeffer, N., Lohmann, C., Möller, W., Voigt, I. 2011. Wirksamkeit der aus dem Konjunkturpaket II geförderten FuE-Projekte des Zentralen Innovations-programms Mittelstand (ZIM). Düsseldorf: RKW Kompetenzzentrum.

Dietzenbacher, E., Los, B., 2002. Externalities of R\&D Expenditures. Economic Systems Research 14, 407-426. 
Duchin, F., Lange, G.-M. 1995. The choice of technology and associated changes in prices in the US economy, Structural Change and Economic Dynamics, 6 (1995), 335-357.

European Commission, 2011. Innovation Union Competitiveness Report.

European Commission, United Nations, International Monetary Fund, Organization for Economic Development, World Bank, 2009. System of National Accounts 2008, New York.

Friedman, M. 1957. A theory of consumption functions. Princeton University Press.

Godin, B. 2007. Science, accounting and statistics: The input-output framework, Research Policy, 36, 1388-1403

Grossman, G.M., Helpman, E., 1992. Innovation and Growth in the Global Economy. The MIT Press: Cambridge.

González, X., Pazó, C., 2008. Do public subsidies stimulate private R\&D spending? Research Policy 7, 371-389.

Grady, P., Muller, R. A. 1988. On the use and misuse of input-output based impact analysis in evaluation. The Canadian Journal of Program Evaluation, 3 (2), 49-61.

Guellec, D., van Pottelsberghe de la Potterie, B., 2001. R\&D and Productivity Growth: Panel Data Analysis for 16 OECD Countries. Oxford Bulletin of Economics and Statistics, OECD Economic Studies, 103-125.

Günther, J., Dominguez Lacasa, I., Fritsch, M., Nulsch, N., Slavtchev, V., Schwartz, M., Titze, M., Wilde, K., 2010. Evaluierung des Programms des Sächsischen Staatsministeriums für Wissenschaft und Kunst (SMWK) zur Förderung von Projekten im Forschungsbereich, IWH-Sonderhefte 1/2010. Halle: IWH.

Günther, J., Michelsen, C., Peglow, F., Titze, M., Fritsch, M., Noseleit, F., Schröter, A. 2008. Evaluierung der FuE-Projektförderung des Sächsischen Staatsministeriums für Wirtschaft und Arbeit - Endbericht, IWH-Sonderhefte 3/2008. Halle: IWH.

Haukness, J., Knell, M., 2009. Embodied knowledge and sectoral linkages: An input-output approach to the interaction of high- and low-tech industries. Research Policy 38, 459-469. 
Heppke-Falk, K. H., J. Tenhofen und G. B. Wolff 2006. The Macroeconomic Effects of Exogenous Fiscal Policy Shocks in Germany: A Dissaggregated SVAR Analysis, Bundesbank Discussion Paper, 41.

Hujer, R., Kokot, S. 2001. Frankfurt Airport's impact on regional and national employment and income. In: Pfähler, W. (ed.) Regional Input-Output-Analysis, Nomos, Baden-Baden, 111155.

Katz, R. L., Vaterlaus, S., Zenhäusern, P., Suter, S. (2010) The Impact of Broadband on Jobs and the German Economy. Intereconomics, 45 (1), 26-34.

Kleer, R. 2009. Government R\&D subsidies as a signal for private investors, Research Policy, $39,1361-1374$.

Kulicke, M., Hufnagl, M., Brandt, T., Becker, C., Berteit, H., Grebe, T., Kirbach, M., Lübbers, T., 2010. Evaluierung des Programmstarts und der Durchführung des „Zentralen Innovationsprogramms Mittelstand (ZIM)“, Study on behalf of the Federal Ministry of Economics and Technology. Fraunhofer ISI. Karlsruhe, Berlin.

Lerner, J. 1999. The Government as Venture Capitalist: The Long-Run Impact of the SBIR Program, Journal of Business, 72, 285-318.

Levy, D.M., Terleckyj, N.E., 1983. Effects of Government R\&D on Private R\&D Investment and Productivity: A Macro-economic Analysis. Bell Journal of Economics 14, 551-61.

Malerba, F., 1992. Learning by Firms and Incremental Technical Change. The Economic Journal 102, 845-859.

Meuleman, M. and De Maeseneire, W. 2012. Do R\&D subsidies affect SMEs' access to external financing? Research Policy, 41, 580-591.

Miller, R.; Blair, P. 2009. Input-Output-Analysis. Foundations and Extensions, 2nd ed., Cambridge.

OECD, 2002. Frascati Manual. Proposed Standard Practice for Surveys on Research and Experimental Development, 6th edition, Paris: OECD.

OECD, 2008. OECD Science, Technology and Industry Outlook. Paris: OECD.

OECD 2009. Policy Responses to the Economic Crisis: Investing in Innovation for Long-Term Growth. Paris: OECD. 
Oltmanns, E., Bolleyer, R., Schulz, I., 2009. Forschung und Entwicklung nach Konzepten der Volkswirtschaftlichen Gesamtrechnung. in: Wirtschaft und Statistik, Statistisches Bundesamt, 2/2009, S.125-135.

Pavitt, K., Robson, M., Townsend, J. 1989. Technological accumulation, diversification and organisation in UK companies. 1945 - 1983. Management Science 35 (1), 81-99.

Paunov, C. 2012. The global crisis and firms‘ investments in innovation. Research Policy 41, 24-35.

Rammer, C., 2009. INNO-Policy TrendChart - Innovation Policy Progress Report for Germany, DG ENTR, European Commission, Brussels: 2009.

Romer, P., 1986. Increasing returns and long run growth. Journal of Political Economy 94, $1002-1037$

Romer, P., 1990. Endogenous technological change, Journal of Political Economy 98, S71S102.

Romp, W. und J. de Haan 2007. Public Capital and Economic Growth: A Critical Survey, Perspektiven der Wirtschaftspolitik, 8, 6 - 52.

Rose, A. (1996): Input-output economics and computable general equilibrium models, Structural Change and Economic Dynamics 6, 295-304.

Schwartz, M., Peglow, F., Fritsch, M., Günther, J. 2012. What Drives Innovation Output from Subsidized R\&D Cooperation? - Project-level Evidence from Germany, Technovation, $32(6), 358-369$.

Segerstrom, P. S. 2000. The Long-Run Growth Effects of R\&D Subsidies, Journal of Economic Growth, 5, 277-305

Shleifer, A. 1986. Implementation Cycles. Journal of Political Economy, 94, 1163-1190.

Takalo, T. and Tanayama, T. 2010. Adverse selection and financing of innovation: is there a need for R\&D subsidies? The Journal of Technology Transfer, 35, 16-41.

Terleckyj, N.E., 1980. "Direct and Indirect Effects of Industrial Research and Development on the Productivity Growth of Industries", in: J.W. Kendrick and B.N. Vaccara (eds), NBER Studies in Income and Wealth, no. 44, University of Chicago Press: Chicago, 359-386. 
van Ark, B., Jaeger, K., Manole, V., Metz, A., 2009. Productivity, Performance, and Progress - Germany in International Comparative Perspective. Study on behalf of Friedrich-EbertFoundation, Bonn: April 2009. 